\title{
DEVELOPMENT AND VALIDATION OF UV-VISIBLE SPECTROPHOTOMETRIC METHOD FOR ANALYSIS OF BOSENTAN IN SPIKED HUMAN PLASMA
}

\author{
BHAVYA SRI K. ${ }^{1}$, MOUNIKA C. H. ${ }^{2}$ \\ 1,2Department of Pharmaceutical Analysis, RBVRR Women's College of Pharmacy, Hyderabad, India \\ Email: bhavya.khagga@gmail.com
}

Received: 15 Apr 2019, Revised and Accepted: 26 Jun 2019

\section{ABSTRACT}

Objective: The aim of the present study is to develop and validate a simple, efficient, economical and accurate UV-visible spectrophotometric method for estimation of bosentan in spiked human plasma.

Methods: The analyte was extracted by Liquid-liquid Extraction (LLE) procedure using acetonitrile and chloroform. Absorbance of the analyte in the extract was measured at $270 \mathrm{~nm}$ using ethanol as a diluent. The developed method was validated for linearity, accuracy and robustness.

Results: The proposed method was found to be linear in the range of 6 to $18 \mu \mathrm{g} / \mathrm{ml}$. The correlation coefficient ( $\left.\mathrm{r}^{2}\right)$ was found to be 0.99 . The results revealed that the linearity, accuracy and robustness of the developed method were within the acceptable range.

Conclusion: The analytical technique presented here demonstrates shorter and easier sample preparation method, decreased analysis time and reduces the need for complicated or expensive equipment. The sample preparation method used in this study can also be further extended to higherend analytical techniques and other biological samples for quantification of bosentan.

Keywords: Bosentan, Liquid-liquid extraction, Plasma, UV-Visible spectrophotometer, Acetonitrile

(c) 2019 The Authors. Published by Innovare Academic Sciences Pvt Ltd. This is an open access article under the CC BY license (http://creativecommons.org/licenses/by/4.0/) DOI: http://dx.doi.org/10.22159/ijcpr.2019v11i4.34937

\section{INTRODUCTION}

Bosentan monohydrate chemically 4-tert-butyl-N-[6-(2-hydroxyethoxy)-5-(2-methoxyphenoxy)-2-pyrimidin-2-ylpyrimidin-4-yl] benzene sulfonamide hydrate is dual Endothelin Receptor Antagonist (ERA) with molecular formula of $\mathrm{C}_{27} \mathrm{H}_{29} \mathrm{~N}_{5} \mathrm{O}_{6} \mathrm{~S} \cdot \mathrm{H}_{2} \mathrm{O}$ [1]. It is used to treat Pulmonary Arterial Hypertension $(\mathrm{PAH})$ and chronic heart failure. It is a specific and competitive antagonist of endothelin-1 which is potent endogenous vasoconstrictor acting on both endothelin $A$ and endothelin $B$ receptors of the smooth muscles of pulmonary blood vessels leading to high blood pressure [2, 3]. Bosentan has a slightly higher affinity for ETA receptors than for ETB receptors. ET-1 concentrations are elevated in plasma and lung tissue of patients with pulmonary arterial hypertension, suggesting a pathogenic role for ET1 in this disease [4]. Bosentan blocks the binding of endothelin to its receptors, thereby eliminating endothelin's deleterious effects [5].

A literature search revealed that there are several quantitative analytical methods for estimation of bosentan in biological samples; these methods include gradient RP-HPLC, SPE-LC-MS/MS etc., which are expensive and complex to perform in conventional bioanalytical laboratories [6-9]. Thus, it was decided to develop and validate an alternate simple, rapid, economical and robust method which was based on LLE for sample preparation and UV-visible Spectrophotometer for determination of bosentan in spiked human plasma.

Structure of bosentan<smiles>COc1ccccc1Oc1c(NS(=O)(=O)c2ccc(C(C)(C)C)cc2)nc(-c2ncccn2)nc1OCCO</smiles>

\section{MATERIALS AND METHODS}

\section{Equipment}

The instrument used was Elico SL 210 Double Beam UV-VIS Spectrophotometer [10-14] with silicon photo diode detector. The data acquisition was done on Spectratreats software. Other equipment used in the study was REMI R-8C centrifuge.

\section{Materials}

Pharmaceutical grade bosentan was obtained as a gift sample from Hetero Drug Laboratories, Hyderabad, India. Blood was collected from individuals not taking drug and plasma was separated and frozen in polypropylene micro-tubes at- $20^{\circ} \mathrm{C}$. Acetonitrile, chloroform and ethanol used in the study were of AR grade $[15,16]$. All the chemicals were purchased from SD Fine Chemicals, Mumbai, India.

\section{Methods}

Preparation of standard stock solution

Accurately $10 \mathrm{mg}$ of bosentan was weighed and transferred into 100 $\mathrm{ml}$ volumetric flask and dissolved in ethanol. Then the volume was made up to the mark with ethanol to produce $100 \mu \mathrm{g} / \mathrm{ml}$ concentration stock solution.

\section{Preparation of working standard solutions}

From the standard stock solution $0.6,0.9,1.0,1.2,1.5$ and $1.8 \mathrm{ml}$ aliquots were pipetted into separate $10 \mathrm{ml}$ volumetric flasks and the volume was made up to the mark with ethanol to get working standard solutions with concentrations of $6,9,10,12,15$ and 18 $\mu \mathrm{g} / \mathrm{ml}$ respectively.

\section{Determination of working wavelength $(\lambda \max )$}

The $\lambda$ max (wavelength of maximum absorption) of bosentan was determined by scanning $10 \mu \mathrm{g} / \mathrm{ml}$ solution of the drug (ethanol used as diluent) using UV-Visible spectrophotometer within the wavelength region of 220 to $400 \mathrm{~nm}$ against ethanol as blank. The absorption curve (fig. 1) showed characteristic absorption maxima at $270 \mathrm{~nm}$ for Bosentan. 


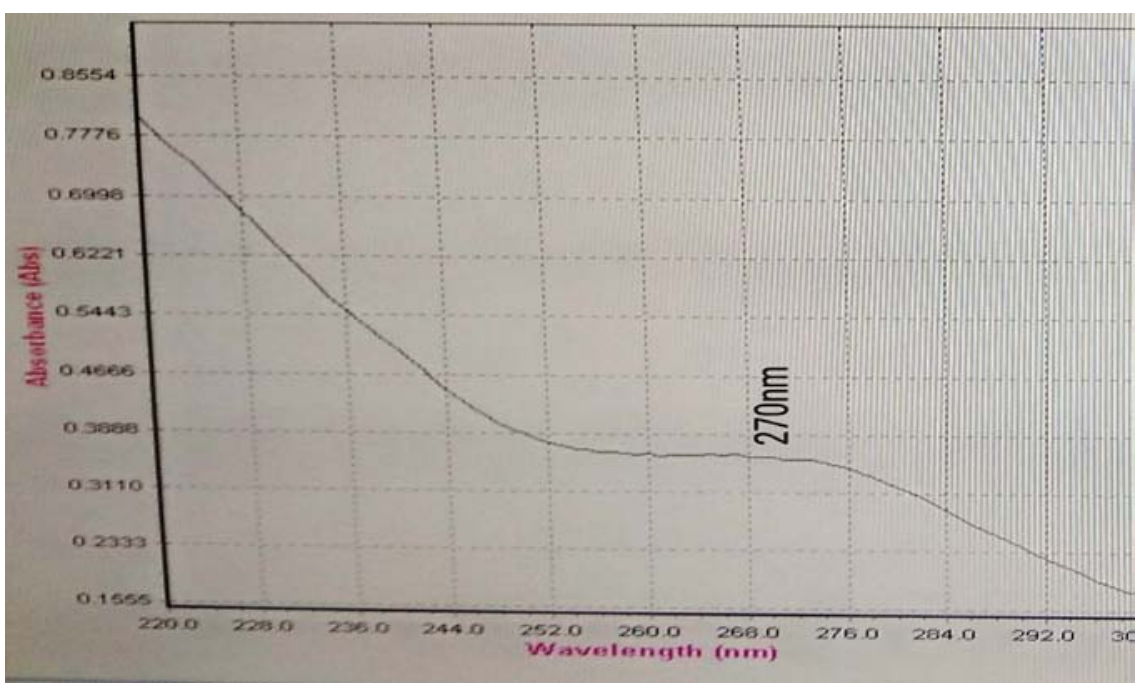

Fig. 1: UV spectrum of standard bosentan solution

\section{Sample preparation}

\section{Spiking procedure}

Appropriately $3 \mathrm{ml}$ of plasma samples was placed in polypropylene tubes with conic bottom and aliquots of bosentan standard solution were spiked at the range 6 to $18 \mu \mathrm{g} / \mathrm{ml}$.

\section{Extraction procedure}

Liquid-liquid Extraction (LLE) method was used. A mixture of $1.5 \mathrm{ml}$ of acetonitrile and $0.25 \mathrm{ml}$ of chloroform was added to the sample solution. A cloudy solution was obtained which was subjected to centrifugation for $5 \mathrm{~min}$ at $3000 \mathrm{rpm}$. The supernatant was collected and evaporated to dryness. The residue was dissolved in $10 \mathrm{ml}$ ethanol and absorbance was measured at $270 \mathrm{~nm}$ using UV-Vis spectrophotometer.

\section{Method validation}

The method validation was done as per the FDA guidelines. The linearity, accuracy, recovery, and robustness parameters were tested.

\section{Linearity}

Linearity of the method was studied by analyzing six standard solutions covering the range of 6 to $18 \mu \mathrm{g} / \mathrm{ml}$. From the primary stock solution $0.6 \mathrm{ml}, 0.9 \mathrm{ml}, 1.0 \mathrm{ml}, 1.2 \mathrm{ml}, 1.5 \mathrm{ml}$ and $18 \mathrm{ml}$ of aliquots were pipetted into $10 \mathrm{ml}$ volumetric flasks and made up to the mark with ethanol to give concentrations of $6 \mu \mathrm{g} / \mathrm{ml}, 9 \mu \mathrm{g} / \mathrm{ml}$ $10 \mu \mathrm{g} / \mathrm{ml}, 12 \mu \mathrm{g} / \mathrm{ml}, 15 \mu \mathrm{g} / \mathrm{ml}$ and $18 \mu \mathrm{g} / \mathrm{ml}$. Calibration curve showing concentration versus absorbance was plotted by measuring absorbance of the prepared working standard solutions at $270 \mathrm{~nm}$ using ethanol as blank. The linearity data is presented in table 1 and calibration curve is shown in fig. 2.

Table 1: Linearity data of bosentan

\begin{tabular}{ll}
\hline Concentration $(\mu \mathrm{g} / \mathrm{ml})$ & Absorbance \\
\hline 6 & 0.264 \\
9 & 0.3642 \\
10 & 0.3901 \\
12 & 0.4707 \\
15 & 0.5651 \\
18 & 0.6756 \\
\hline
\end{tabular}

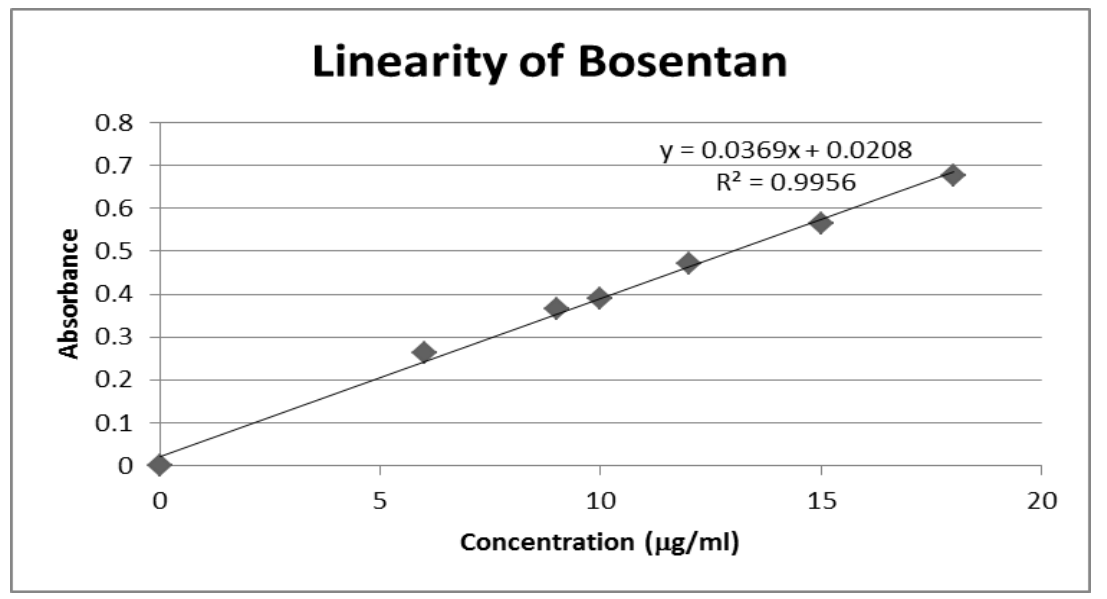

Fig. 2: Calibration curve of bosentan 


\section{Accuracy (Recovery study)}

The accuracy of the method was determined by calculating the recoveries of bosentan by the standard addition method at three levels. Known amounts of standard solutions of bosentan were added at $50 \%, 100 \%$ and $150 \%$ concentration to pre quantified sample solution of bosentan and the amount of drug recovered was estimated. Each level has been analyzed in triplicate. Results are shown in table 2 . The recovery was found to be in between the predefined acceptance criteria of $80.0-120.0 \%$.

\section{Robustness}

Robustness of the method was determined by deliberately altering the $\lambda \max$. Absorbance of the standard solution was measured at $\lambda \max \pm 1 \mathrm{~nm}$ The results of the study (table 3) represented no significant changes in the absorbance illustrating the robustness of the method.

Table 2: Accuracy study data

\begin{tabular}{lll}
\hline Concentration added & Mean \% recovery & \% RSD \\
\hline $50 \%$ & 99.9 & 0.007124 \\
$100 \%$ & 100.02 & 0.005436 \\
$150 \%$ & 98.92 & 0.009791 \\
\hline
\end{tabular}

Table 3: Robustness study data

\begin{tabular}{llll}
\hline S. No. & $\mathbf{2 6 9} \mathbf{~ n m}$ & $\mathbf{2 7 0} \mathbf{~ n m}$ & $\mathbf{2 7 1} \mathbf{~ n m}$ \\
\hline 1 & 0.450 & 0.457 & 0.454 \\
2 & 0.451 & 0.457 & 0.453 \\
3 & 0.451 & 0.456 & 0.454 \\
Mean & 0.450666 & 0.456666 & 0.453666 \\
SD & 0.000546 & 0.000321 & 0.000275 \\
\%RSD & 0.091341 & 0.061352 & 0.042576 \\
\hline
\end{tabular}

\section{DISCUSSION}

The wavelength of $270 \mathrm{~nm}$ was chosen because it was the $\lambda \max$ of bosentan. LLE was performed using chloroform as it has maximum extraction efficiency compared to other solvents like dichloromethane.

\section{CONCLUSION}

A simple, easier, rapid and economical LLE process with UV-Visible spectrophotometric measurement was developed and validated for analysis of bosentan in spiked human plasma. The analytical technique presented in this study decreases analysis time and also the need for complicated or expensive equipment. Therefore, this technique can be used for routine quantitative analysis of bosentan in plasma and other biological samples and can also be further extended to other higher end analytical techniques.

\section{AUTHORS CONTRIBUTIONS}

All the author have contributed equally

\section{CONFLICT OF INTERESTS}

Declare none

\section{REFERENCES}

1. https://pubchem.ncbi.nlm.nih.gov. [Last accessed on 02 Mar 2019].

2. LJ Rubin, DB Badesch, RJ Barst. Bosentan therapy for pulmonary arterial hypertension. New England J Med 2002;346:896-903.

3. Kiowski W, Kim J, Oechslin E, Sutsch G, Hunziker P, Muller P, et al. Evidence for endothelin-1-mediated vasoconstriction in severe chronic heart failure. Lancet 1995;346:732-6.

4. Paul LM, Van Giersbergen, Atef Halabi, Jasper Dingemanse. Singleand multiple-dose pharmacokinetics of bosentan and its interaction with ketoconazole. Br J Clin Pharmacol 2002;53:589-95

5. JM Pearl, SA Wellmann, JL McNamara. Bosentan prevents hypoxiareoxygenation-induced pulmonary hypertension and improves pulmonary function. Annals Thoracic Surgery 1999;68:1714-21.

6. Parekh JM, Shah DK, Sanyal M, Yadav M, Shrivastav PS. Development of an SPE-LC-MS/MS method for simultaneous quantification of bosentan and its active metabolite hydroxybosentan in human plasma to support a bioequivalence study. J Pharm Biomed Anal 2012;70:462-70.
7. Atila A, Ozturk M, Kadioglu Y, Halici Z, Turkan D, Yayla M, et al. Development and validation of UFLC MS/MS method for determination of bosentan in rat plasma. J Pharm Biomed Anal 2014;97:33-8.

8. Xiang J, Jian LZ, Zhe W, Zhisheng X, Ren-ai X. Simultaneous determination of bosentan and glimepiride in human plasma by ultra-performance liquid chromatography tandem mass spectrometry and its application to a pharmacokinetic study. J Pharm Biomed Anal 2014;95:207-12.

9. Yoshinari Y, Miho T, Hideki H, Keita H, Yasuo O, Yuto Y, et al. Simultaneous micro determination of bosentan, ambrisentan, sildenafil, and tadalafil in plasma using liquid chromatography/ tandem mass spectrometry for pediatric patients with pulmonary arterial hypertension. J Pharm Biomed Anal 2014;89:227-32.

10. Gilant E, Bus Kwasnik K, Domel I, Kaza M, Rudzki PJ. Influence of hydroxybosentan on determination of bosentan in human plasma. Peer J Pre Prints 2015;3:e1539v1.

11. Sanaz Sajedi Amin, Karim Assadpour Zeynali, Vahid Panahi Azar, Abbas Kebriaeezadeh, Maryam Khoubnasabjafari, Khalil Ansarin, et al. Spectroscopic analysis of bosentan in biological samples after a liquid-liquid microextraction. BioImpacts 2015;5:191-7.

12. Zamani Kalajahi M, Fazeli Bakhtiyari R, Amiri M, Golmohammadi A, Afrasiabi A, Khoubnasabjafari M, et al. Dispersive liquid-liquid microextraction based on solidification of floating organic droplet followed by spectrofluorimetry for determination of carvedilol in human plasma. Bioanalysis 2013;5:437-48.

13. D Launay, O Sitbon, JL Pavec. Long-term outcome of systemic sclerosis-associated pulmonary arterial hypertension treated with bosentan as first-line monotherapy followed or not by the addition of prostanoids or sildenafil. Rheumatology 2010; 49:490-500.

14. Channick RN, Simonneau G, Sitbon O, Robbins IM, Frost A, Tapson $\mathrm{VF}$, et al. Effects of the dual endothelin-receptor antagonist bosentan in patients with pulmonary hypertension: a randomised placebo controlled study. Lancet 2001;358:1119-23.

15. Bioanalytical Method Validation-U. S. Food and Drug Administration; 2018. p. 1-37.

16. Beghetti M, Haworth SG, Bonnet D, Barst RJ, Acar P, Fraisse A, et al. Pharmacokinetic and clinical profile of a novel formulation of bosentan in children with pulmonary arterial hypertension: the FUTURE-1 study. Br J Clin Pharmacol 2009;68:948-55. 